УДК 911.375:330

\title{
СУСПIIЬHO-ГEOГРАФТ/И/HI ВОСतIAKEHHЯ
}

doi: https://doi.org/10.15407/ugz2018.01.030

\section{I. В. Гукалова \\ Інститут географії Національної академії наук України, Київ \\ ЯКІСТЬ ЖИТТЯ ЯК ЦІЛЬОВИЙ ІМПЕРАТИВ КОНЦЕПЦІЙ МІСЬКОГО РОЗВИТКУ: ВИСНОВКИ ДЛЯ УКРАЇНИ}

\begin{abstract}
Мета публікації - розкриття сутності поняття «міський розвиток» у його взаємозв'язку з якістю життя населення, аналіз досвіду міжнародного співробітництва і розроблення урбаністичних концепцій з особливою увагою до концепції інтегрованого розвитку міст, яка вже сприйнята в Україні. Виклики урбанізації та можливості протидії породженим нею загрозам стали невід'ємною складовою багатьох стратегічних документів, затверджених в останні десятиріччя на міжнародному рівні в галузі просторового і сталого (збалансованого) розвитку. Їх ключовою метою $є$ покращення якості життя населення, а практична реалізація цілей розвитку неможлива без постійного моніторингу проблем, які впливають на стан міської спільноти, ії життєздатність, а також підходів до їх вирішення. Незважаючи на відмінності у прояві наслідків урбанізації в окремих країнах, різні повсякденні практики і моделі трансформації міського простору, потреба у розробленні конкретних стратегій розвитку українських міст потребує аналізу зарубіжного, зокрема європейського, досвіду планування й управління їх розвитком і визначення можливостей його імплементації. Зміни у підходах до міського розвитку розглянуто крізь призму еволюції найвідоміших сучасних концепцій, спрямованих на зниження загального рівня «проблематичності» життя містян. Новизна статті - у постановці завдання дослідження засад міського розвитку з позицій якості життя населення, існуючих концептуальних напрацювань і затверджених міжнародних документів.
\end{abstract}

Ключові слова: якість життя населення; сталий (збалансований) розвиток; урбанізаиія; міський розвиток; Україна.

\section{I.V. Gukalova}

Institute of Geography of the National Academy of Sciences of Ukraine, Kyiv QUALITY OF LIFE AS A GOAL OF URBAN DEVELOPMENT CONCEPTS: CONCLUSIONS FOR UKRAINE

The purpose of this publication is the interpretation of the concept of «urban development» in its relationship with the quality of life concept, the analysis of international cooperation experience and the development of urban concepts with special attention to the integrated urban development approach, which is accepted in Ukraine. The challenges of urbanization and the possibilities of counteracting its threats have become an important part of many international strategic documents approved in recent decades in the framework of spatial and sustainable (balanced) development. Their key goal is to improve the quality of life of the population, and the practical realization of development goals is impossible without continuous monitoring of problems that affect the city community, its viability, as well as approaches to their solution. Despite the differences in the manifestation of the consequences of urbanization in different countries, different common practices and patterns of urban transformation, the need to develop specific strategies for the development of Ukrainian cities requires an analysis of foreign, in particular European, experience in planning and managing their development and determining the possibilities for its implementation. Changes in approaches to urban development are considered through the prism of the evolution of the wellknown modern concepts, each of which aims to reduce the overall level of «problematic» life of cities. The novelty of the article - in the formulation of the task of studying the urban development principles associated with quality of life, existing conceptual drafts and approved international documents.

Key words: quality of life; sustainable development; urbanization; urban development; Ukraine.

\section{Актуальність дослідження}

В умовах активізації євроінтеграційних процесів впровадження політики сталого (збалансованого) міського розвитку має стати невід'ємною

() І.В. Гукалова, 2018 складовою державної регіональної політики в Україні. Узгодження глобальних, національних, регіональних та місцевих концепцій, стратегій $\mathrm{i}$ програм просторового розвитку держави потребують уваги до оцінки ступеня збалансованості iii урбаністичного поступу з позицій якості жит- 
тя населення. Це особливо актуально у зв'язку 3 процесом децентралізації, збільшенням в останні роки масштабів внутрішньої міграції населення, потребою у формуванні економічних полюсів зростання $з$ одночасним пожвавленням розвитку сільської місцевості - основи безпечного і збалансованого розвитку українських міст.

Сучасні міста - основні носії економічного, соціокультурного, наукового, освітнього, демографічного потенціалів України, тому забезпечення сталого міського розвитку є актуальним завданням, бачення якого має бути науково обгрунтованим і стратегічно оформленим. Врахуванню підлягають чимало чинників: історія виникнення міст та освоєння території, економічний потенціал і наявна інфраструктура, природні ресурси і географічне положення конкретних поселень. Особливо важливим $є$ врахування потреб та інтересів населення, адже саме людина та іiі добробут $\epsilon$ ключовими рушіями розвитку.

У 2015 р. Генеральна Асамблея ООН затвердила підсумковий документ «Порядок денний в галузі сталого розвитку на період до 2030 р.». Ціль 11 цього документу безпосередньо стосується проблем урбанізації, а уряди країн, у т.ч. України, взяли на себе зобов'язання забезпечити відкритість, безпеку, життєздатність та екологічну стійкість розвитку міст і громад. Ця ціль об'єднала економічні, соціальні, демографічні, культурологічні, екологічні аспекти життя суспільства. Йдеться про забезпечення інтегрованого розвитку міст, фундаментальною метою якого стає поліпшення якості життя населення, вирішення проблем його адаптації до екологічних, соціальних, працересурсних, соціокультурних наслідків урбанізації, трансформації соціуму і простору.

У вітчизняній науковій літературі питання сталого міського розвитку і сучасних процесів трансформації міст у контексті якості життя i нових просторових тенденцій тільки починають осмислюватися $[3,5,6,10,14,17,20]$. Контекст розгляду проблем дуже широкий - від просторових і соціальних аспектів урбанізації до пошуку шляхів імплементації зарубіжного досвіду управління містами.

Найпродуктивнішим науковим напрямом, що об'єднав фахівців різних країн у проблемному полі й підходах до розгляду урбанізації як феномену, пов'язаного не лише зі зростанням частки міського населення, стала геоурбаністика, в поле зору якої потрапляє еволюція, просторова організація i функціонування міських систем з урахуванням рівня розвитку, способу, умов та якості життя населення.

В Україні вже відомі практичні ініціативи у розробленні та реалізації планів інтегрованого міського розвитку за участю Німецького товариства міжнародного співробітництва (GIZ), Федеральних міністерств Німеччини з навколишнього середовища, охорони природи, будівництва та ядерної безпеки та 3 економічного співробітництва та розвитку, Міністерства регіонального розвитку, будівництва та житлово-комунального господарства України. Зокрема, у 2017-2018 pр. у рамках проекту «Сильні міста - сильна Україна» передбачено відбір і впровадження інфраструктурних проектів для розвитку більш інклюзивних, прийнятних для життя та економічно ефективних міст і скорочення викидів парникових газів у чотирьох обласних центрах - Вінниці, Житомирі, Полтаві та Чернівцях [11].

М е т а цієї публікації полягає у розкритті сутності поняття «міський розвиток» у його взаємозв'язку з якістю життя населення, аналізі досвіду міжнародного співробітництва й розроблення урбаністичних концепцій з особливою увагою до концепції інтегрованого розвитку міст, яка вже сприйнята в Україні.

\section{Виклад основного матеріалу \\ Урбанізація і міський розвиток у координатах якості життя населення}

Одним із стрижневих процесів зміни якості життя населення в Україні є урбанізація, особливості перебігу і наслідки якої, зокрема суспільно-географічні, надовго визначили територіальну диференціацію розселення, виробництва, моделей поведінки населення і способів сприйняття світу, а також тих проблем, які значно загострилися у сучасний період. 3 іншого боку, в процесі управління розвитком міст важливим $\epsilon$ забезпечення максимально комфортних умов життєдіяльності для кожного жителя, його потреб у праці, споживанні різних послуг, відпочинку тощо.

Серед найвідоміших теорій просторового розвитку в аспекті якості життя населення слід виділити два великі напрями - модернізм та постмодернізм. У 1980-тих роках прихильники модернізму прагнули до найраціональнішого використання ресурсу території для найповнішого забезпечення потреб економіки і громади міста. Вирішального значення при цьому надавалося 
простоті та функціональності планування міста, проте впровадження стандартизації у містобудуванні призвело до однотипності забудови і втрати багатьма містами своєї самобутності. Прикладом цього стали т.з. «спальні райони» 3 багатоповерховою панельною забудовою, які існують у багатьох містах країн Східної Європи. Для таких районів характерним є низький рівень розвитку соціальної інфраструктури, незадовільний стан інженерних мереж, нерідко - високий рівень злочинності тощо [13].

Постмодернізм грунтується на трьох тезах про існування різних людських потреб, способів висловлення цих потреб, форм організації міського простору. Головна ідея - орієнтація на забезпечення потреб містян у комфортному середовищі та зміцнення різних форм суспільного життя. Акцент зміщується від раціонального використання території до використання інтегрального потенціалу міста (а часто - i його оточення) в інтересах людини.

Урбанізація на різних своїх стадіях і в особливих проявах змінила життя більшості країн світу. Зростання міського населення і міст означали новий уклад життя, нові взаємодії й навантаження, що не минуло безслідно в жодній країні світу. Настає час розрізняти вузьке розуміння урбанізації (зростання міського населення) і широке (як процесу міського розвитку, що супроводжується формуванням відповідних соціальної організації, умов та способу життя населення та їх поширенням на сільську місцевість, а також відповідною управлінською діяльністю, спрямованою на забезпечення сприятливого середовища життедіяльності людей). Виявляється, що зростання міського населення не завжди і не всюди супроводжується всебічним розвитком міст. Цей дисонанс найменше виражений у розвинених країнах; там термін Urban development (міський розвиток) взагалі домінує над терміном Urbanization (зростання міст і міського населення). Найбільше він проявляється у країнах, що розвиваються. Своєї специфіки на хвилі індустріалізації та ідеологізації він набув і у постсоціалістичних країнах, у т.ч. в Україні.

Все це стало підставою для пошуку шляхів подолання проблем розвитку міст, різних для країн світу, проте однакових у ціннісному спрямуванні щодо їх розв'язання.

Міста, з одного боку, є реально існуючими географічними об'єктами, з іншого боку, являють собою певний діяльнісний простір (економічний, соціальний, культурний, інформаційний тощо). Межі географічного і діяльнісних просторів можуть не збігатися і це принципово для розуміння поняття «міський розвиток». Розширення діяльнісного простору міста до масштабів глобальної економіки в різних сферах життєдіяльності передбачає налагодження комунікації між різними агентами, які присутні в діяльнісному просторі міста, розуміння його суб'єкт-об'єктної природи. Місто виступає суб'єктом тією мірою, якою воно здатне визначати власне майбутнє, залучати ресурси для розвитку, впливати на попит та пропозицію на глобальних і національних ринках тощо.

Отже, вимоги до змісту міського розвитку значно ускладнюються і не обмежуються питаннями проектування його планувальної структури.

Фахівці трактують розвиток міст як: «об'єктивно сформовану систему функціонування суб'єктів території (міста), засновану на стійкому та збалансованому відтворенні соціально-економічного, природно-ресурсного, інноваційного, економічного та іншого потенціалів, спрямованих на підвищення якості життя населення і збільшення внеску муніципального утворення у національну економіку» [19].

У нинішніх умовах, на нашу думку, орієнтиром має бути стабільний $i$ гармонійний розвиток міських поселень в їх взаємодї із сільською місиевістю на основі дієвої економіки, сталого відтворення людського потениіалу та його ефективної зайнятості, збільшення рівня і поліпшення якості життя населення, у т.ч. за рахунок максимального використання інтегрального потениіалу території. При цьому у поле зору потрапляють всі «зрізи» якості життя: матеріальний, пов'язаний зі здоров'ям населення, його відтворенням і добробутом; функиіональний, де життя оцінюється з точки зору потреб і можливостей людини у взаємодії з соціально-економічними, культурними, екологічними та іншими «просторами»; системно-соціальний, який розкриває особливості середовища життя, його відповідність вимогам безпеки.

\section{Розвиток міст у рамках глобального співробітництва ООН}

Проблеми урбаністичного поступу тривалий час розглядаються у рамках глобальної концепції сталого розвитку, а імплементація останньої супроводжується спрямуванням свідомості в бік «місь- 
кого» мислення, міських ініціатив і проектів. Урбанізація - історичний феномен, тому їі єдиного загальновизнаного визначення не існує. На наш погляд, для кожного етапу розвитку суспільства має бути розроблене своє визначення урбанізаuіï, враховуючи нелінійність та інерційність цього процесу. Відзначимо, що єдиного підходу до трактування поняття «урбанізація» немає навіть серед структурних підрозділів ООН (таблиия 1).

Оскільки проблеми економічного, соціального та екологічного розвитку інтенсивніше проявляються у містах, то питання міського розвитку цілком обгрунтовано включають до угод і організаційних заходів міжнародного рівня. Міста розглядаються як «піонери» щодо впровадження результатів науково-технічного прогресу з метою формування конкурентоспроможної стратегічної перспективи розвитку регіонів та держав і забезпечення високих стандартів життя населення. У свою чергу, якість життя населення слід розглядати не як просту сукупність соціальних показників розвитку, а як системний об'єкт стратегії забезпечення збалансованого розвитку територій різного рівня, у т.ч. міст, що пов'язує економічні, інвестиційні рішення 3 цільовими результатами покращення умов життя населення (насамперед екологічних).

Визнання виняткової ролі міських поселень у процесі забезпечення збалансованого розвитку держав світу відображається на хронології подій, пов'язаних із ініціативами, заходами і документами сталого розвитку, у т.ч. сталого розвитку населених пунктів (рис.1).

3 часу рішення про заснування Програми ООН 3 населених пунктів (ООН-Хабітат) минуло майже 40 років, відтоді актуальність міжнародного співробітництва у галузі розвитку поселень неухильно зростає. Конференції Хабітат відбуваються раз на 20 років і визначають глобальний порядок денний для політики у сфері розвитку населених пунктів на різних територіальних рівнях. Хабітат I відбувся 1976 р. у Ванкувері (Канада), Хабітат II - в 1996 р. у Стамбулі (Туреччина), Хабітат III - 2016 р. у Кіто (Еквадор). Ключові зустрічі ООН з питань сталого розвитку, такі як Всесвітній саміт зі сталого розвитку у 2002 р. та Pio+20 у 2012 р., послідовно підтверджували основні положення Програми Хабітат.

Ключовою темою останньої конференції Хабітат III був сталий (забалансований) розвиток мicm, підставами для обрання якої стали два основних аргументи: 1) глобальна урбанізація злиденності - тобто поширення останньої не тільки у сільських, але більш інтенсивно - у міських поселеннях; 2) визначальна роль міст у забезпеченні екологічної стійкості й зміні клімату. Стаття 27 Нового порядку денного міського розвитку, прийнятого на цій конференції, стверджує, що націо-

Таблиця 1.

Визначення поняття «урбанізація» міжнародними організаціями

\begin{tabular}{|c|c|}
\hline Визначення & Джерело \\
\hline $\begin{array}{l}\text { Зростання міст унаслідок переміщення населення із сільських } \\
\text { районів у пошуках кращої роботи і кращих умов життя }\end{array}$ & $\begin{array}{l}\text { THE WORLD BANK } \\
\text { [URL: http://www.un.org/ru/ } \\
\text { youthink/urbanization.shtml] }\end{array}$ \\
\hline $\begin{array}{l}\text { Процес концентрації населення в містах внаслідок міграції } 3 \\
\text { сільських районів або збільшення кількості міських районів }\end{array}$ & $\begin{array}{l}\text { UN-HABITAT } \\
\text { [URL: http://unhabitat.org/time-to-think- } \\
\text { urban-un-habitat-brochure-2013] }\end{array}$ \\
\hline $\begin{array}{l}\text { Процес, який описує зміни в популяції невеликих сільських } \\
\text { поселень, де сільське господарство є домінуючою сферою } \\
\text { економічної активності, і популяції, зосередженої у великих, } \\
\text { щільно населених міських поселеннях, які характеризуються } \\
\text { домінуванням промисловості та сфери послуг }\end{array}$ & $\begin{array}{c}\text { UNFPA } \\
\text { Фонд народонаселення ООН } \\
\text { [URL: http://www.unfpa.org/urbanization] }\end{array}$ \\
\hline $\begin{array}{l}\text { Процес збільшення частки міського населення, який } \\
\text { супроводжується зростанням економічної, політичної й } \\
\text { культурної значущості міст порівняно з сільською місцевістю }\end{array}$ & $\begin{array}{c}\text { Департамент ООН з економічних і соціальних } \\
\text { питань } \\
\text { [URL: http://gtmarket.ru/ratings/ } \\
\text { urbanization-index/info] }\end{array}$ \\
\hline $\begin{array}{l}\text { Глобальний процес зміни соціального та екологічного } \\
\text { ландшафту на кожному континенті. С результатом міграції } \\
\text { населення } 3 \text { сільських районів на додаток до природного } \\
\text { міського демографічного росту }\end{array}$ & $\begin{array}{c}\text { BOO3 } \\
\text { [URL:http://www.who.int/globalchange/ } \\
\text { ecosystems/urbanization/ru/] }\end{array}$ \\
\hline
\end{tabular}




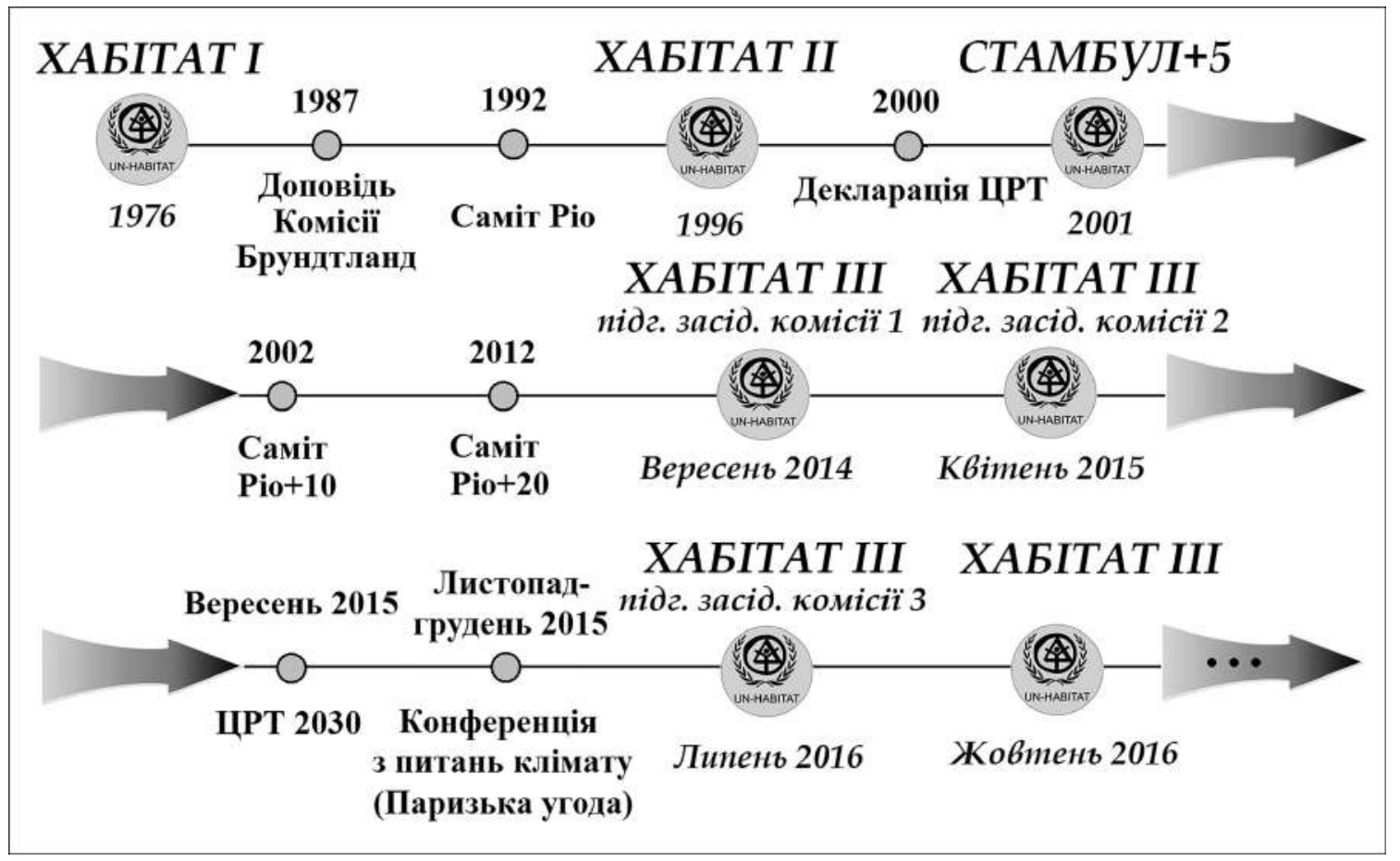

Puc. 1. Проблематика розвитку міст у хронологічних рамках міжнародного співробітництва $\mathrm{OOH}$

нальним, субнаціональним і місцевим органам управління та всім зацікавленим сторонам належить взяти на себе зобов' язання «сприяти рівному розподілу можливостей і переваг, які здатна запропонувати урбанізація і які дозволяють усім жителям, незалежно від того, живуть вони в організованих чи неорганізованих поселеннях, мати нормальне, гідне життя, що приносить задоволення, і повністю реалізувати свій людський потенціал» ${ }^{1}$.

Принципи формування комфорту і сприятливих умов життя населення в рамках забезпечення сталого урбаністичного розвитку закладені й у діяльність глобальної асоціації міст і місцевих урядів ICLEI - Local Governments for Sustainability (International Council for Local Environmental Initiatives) ${ }^{2}$. Аналогічні принципи закладені в систему координат для європейських стійких міст (The Reference Framework for Sustainable Cities: a European Vision) ${ }^{3}$.

\footnotetext{
${ }^{1}$ The New Urban Agenda. URL: http://habitat3.org/the-newurban-agenda

2 Official site of the International Council for Local Environmental Initiatives. URL: http://www.iclei.org/

${ }^{3}$ Council of European Municipalities and Regions. URL: http://www.ccre.org/activites/view/25\#
}

32014 р. сталий міський розвиток є однією 3 ключових цілей стратегії регіонального розвитку «Європа 2020: стратегія розумного, стійкого і всеосяжного зростання».

У контексті інтегрування проблем якості життя населення у конкретні документи слід особливо відзначити такі з них:

- Європейська хартія місцевого самоврядування, 1985 р., Страсбург;

- Стратегія європейського регіонального планування, 1988 р., Лозанна-Страсбург;

- «Порядок денний на XXI століття», 1992 р., Ріо-де-Жанейро;

- Хартія «Міста Європи на шляху до сталого розвитку» (Ольборзька хартія), 1994 р., Ольборг;

- «Порядок денний Хабітат II», 1996 р., Стамбул;

- Принципи сталого просторового розвитку Європейського континенту (СЕМАТ), 2000 р., Ганновер;

- Соціальна хартія міст-членів Союзу Балтійських міст, 2001 р., Росток;

- Лейпцизька Хартія сталого європейського міста, 2007 р., Лейпциг;

- Нова програма урбаністичного розвитку, 2016 р., Кіто.

ISSN 1561-4980. Ukr. geogr. ž, 2018, 1(101) 
Основні стратегічні цілі, визначені цими документами, створюють підгрунтя для розроблення концепцій розвитку міст не лише у країнах $Є_{\text {вро- }}$ пи, а й в інших країнах, що обрали вектор сталого (збалансованого) розвитку, у т.ч. в Україні.

Еволюція сучасних підходів: від нового урбанізму до інтегрованого міського розвитку

Виникнення концепцій міського розвитку пов'язане з особливостями певного періоду розвитку міст, необхідністю вирішення конкретних проблем.

Зокрема, наприкінці 1980-х років виразною тенденцією урбанізації у розвинених країнах стало т.3. «розповзання» міст: наявність доріг і доступність особистого автотранспорту призвели до інтенсивної субурбанізації- появи приміських територій з низькою щільністю забудови, територіально віддалених від центрів міст, у яких масово селилися представники середнього класу. Це явище стало характерним передусім для США, де формат приміського життя при зайнятості населення у місті став дуже поширеним, а планування американських міст відбувалось 3 урахуванням щоденних переміщень на автомобілі. Згодом ця тенденція поширилися на країни Свропи, Японію, Китай. Відзначимо, що приміське життя (щоправда, зовсім в іншому втіленні) набуває поширення і в Україні, при цьому транспортні затори на в'їзді-виїзді з великих міст, екологічне перевантаження і величезні втрати часу при користуванні власним автотранспортом уже стали реальністю нашого життя.

За таких обставин виникла концепція «нового урбанізму» - руху за відродження, оновлення міст і упорядкування урбаністичного простору в них на противагу безконтрольній забудові передмість. В американському варіанті це означало прагнення сформувати повнокровні нові міста 3 пішохідною доступністю всіх видів послуг і місць прикладання праці [16], в європейському - оновлення й реконструкцію колишніх промислових зон і відтворення якостей старовинних міст, кварталів. Концепція була спрямована на повернення місту його первісної ролі каталізатора соціальних відносин. Частково це стало протидією ситуації, за якою міста сприймалися, проектувалися і розвивалися як виробничі системи, при цьому інфраструктура, структура розселення і організації простору створювались 3 метою забезпечення безперебійного функціонування виробничих процесів. Але функціональна диференціація території міст на житлові, офісні, розважальні й виробничі зони спричинила появу просторів дискретного і неповноцінного використання. Переміщення типовим західним містом набувало транзитного характеру: для реалізації повсякденних потреб та інтересів людина мала щодня долати величезні дистанції, створюючи додатковий екологічний пресинг на середовище [12].

Новий урбанізм став першою концепцією міського розвитку, спрямованою на покращення якості життя населення - його здоров'я (внаслідок переміщення пішки або на велосипеді, появи нових місць активного відпочинку і зелених зон), безпеки (зниження злочинності у зв'язку з освітленням i оформленням вулиць та відсутністю покинутих територій), на ефективне використання громадської й комерційної інфраструктури, зростання рівня життя малозабезпечених сімей $\mathrm{i}$ низькомобільних груп населення, стимулювання економічного зростання за рахунок транспортної доступності місць праці, продуктивності праці тощо. На хвилі «нового урбанізму» розробляються й затверджуються концепції сталого міста Європейського Союзу і Ольборзькі зобов'язання ${ }^{4}$, популярними стають концепції міських селищ, (urban village) [2], екоміст [18], зручних для житmя міст [22] та інші.

У 2000-тих роках інтеграція соціокультурного та екологічного підходів була відображена в концепції екополісу [4], що передбачає зелену економіку і альтернативну енергетику, компактну забудову, участь громад у проектуванні міського розвитку, пішохідні зони, наявність близької інфраструктури, транзитні коридори, утилізацію відходів і повторне використання води. Аналогічний підхід був запропонований Організацією економічного співробітництва та розвитку (ОЕСР) у концепції «зеленого зростання» - економічного зростання за одночасного зниження шкідливих викидів і збереження біорізноманіття [15].

Разом із соціально-екологічними концепціями міського розвитку у цей період з'являються концепції, які спираються на управління знаннями, людський капітал, інновації та застосування інформаційно-комунікаційних технологій. Найвідомішими серед них стали: концепція «міста, що навчається», яка передбачає перехід від традиційної до інтерактивної освіти, освіту і обмін

\footnotetext{
4 Sustainable Cities Platform. URL: http://www. sustainablecities.eu/the-aalborg-commitments/
} 
знаннями в процесі практичної діяльності та взаємодії між фірмами, організаціями і планування на основі цього розвитку міст; концепція «місто знань», спрямована на розвиток економіки знань; «інтелектуального міста», здатного створювати інновації за умов невизначеності; «цифррового місma» 3 всебічним Інтернет-представленням усіх функцій реального міста, включаючи соціальні, культурні, політичні, управлінські. Чільне місце посідає й концепція «креативних міст», спрямована на створення привабливого міського середовища, що сприяє залученню та утриманню талантів. Згідно $з$ нею, найважливішим ресурсом міста є його жителі, їх здатність до нетривіальних рішень, творчості та підприємництва [21].

За останнє десятиріччя парадигма міського розвитку ще більше наблизилися до людини, ïi потреб, інтересів, мотивів поведінки, психологіі, способу і стилю життя. У книзі «Тріумф міста» iii автор, Гарвардський економіст Е. Глейзер, викладає причини, через які люди переїжджають у сучасні міста [7], наголошуючи не на негативних наслідках урбанізації, а на позитивних аспектах проживання у місті - як таких, що мають підтримуватися містобудівними та іншими рішеннями.

Показовим у цьому плані $є$ дослідження ОЕСР, присвячене сталому місту в старіючому cycniльстві [1], де місто розглядається як місце для комфортного життя й діяльності старшого покоління, а міське середовище досліджується 3 позицій потреб пенсіонерів. Згідно з його висновками, місто, яке є зручним для життя людей похилого віку, має вважатися комфортним для всіх груп населення.

Політикою, яка об’єднала різні підходи і концепції, стала політика інтегрованого міського розвитку, яка давно була тематичною стратегією в країнах СС, але у зв'язку з прийняттям у 2007 р. Лейпцизької Хартії «Міста Свропи на шляху сталого розвитку» ${ }^{5}$ набула особливої актуальності. Під політикою інтегрованого міського розвитку, як правило, мають на увазі одночасне і справедливе врахування максимального числа потреб та інтересів, релевантних для розвитку міст і навколишніх територій. Вона є діяльністю 3 поєднання просторових, секторальних і тимчасових аспектів ключових сфер розвитку, яка передбачає

${ }^{5}$ Leipzig Charter on Sustainable European Cities. Final draft (2007). URL: http://ec.europa.eu/regional_policy/archive/ themes/urban/leipzig charter.pdf узгодження потреб бізнесу у розвитку території i тих переваг, які може надати той чи інший планувальний проект населенню.

Модель інтегрованого управління розвитком міст декларує збереження й раціональне використання природних ресурсів як передумови для використання економічних засобів для досягнення благополуччя людини і поліпшення якості іiі життя. Природним ресурсам відводиться роль «механізмів життєзабезпечення», економічна діяльність розглядається лише як засіб для використання цих ресурсів, а діяльність людини як постійне перетворення природних та інших ресурсів на якість життя. Ця модель охоплює не тільки бізнес-сферу, але й будь-який вид діяльності, який відбувається в домогосподарствах, на відпочинку тощо.

У парадигмі інтегрованого міського розвитку первинними $є$ не кількісні, а якісні параметри, не стільки квадратні метри збудованого житла, скільки якість середовища проживання людини, ефективність використання земельних, енергетичних та інших ресурсів, інтенсивність та різноманітність комунікацій та діяльності на території міста, активність і залученість до процесу містотворення різних груп населення. Регулювання землекористування, містобудівної діяльності та просторового розвитку стає засобом покращення якості життя. Політика інтегрованого міського розвитку передбачає розділення міського управління на «синтетичні», але не вузькогалузеві політики: земельну, бюджетну, інфраструктурну, екологічну, транспортно-логістичну, інформаційну, соціокультурну, кожна 3 яких має виходити за межі профільних інтересів. На основі синергії галузевих можливостей і міждисциплінарних підходів, які використовують сучасні концепції міського розвитку, місто може поліпшувати свої якісні параметри, спираючись не тільки на власні сили, а й на партнерство з іншими зацікавленими у його розвитку сторонами.

Інтегрований розвиток міст передбачає постійний перегляд проблем і завдань місцевого і регіонального масштабу щодо досягнення цілей сталого розвитку, оскільки місцеві проблеми можуть швидко змінюватися в умовах сучасного суспільного поступу.

Сучасна українська геоурбаністика сконцентрована на питаннях, які $\epsilon$ актуальними для інших країн, у т.ч. розвинених. Це проблеми збалансованості розвитку міст, оновлення мікрорайонів, 
запровадження альтернативних видів транспорту, інформаційно-комунікаційного розвитку. Водночас існує низка системних бар'єрів, характерних для міського розвитку в Україні, які перешкоджають впровадженню найкращих зарубіжних концепцій. Зазначимо лише окремі з них.

По-перше, міста в Україні не повністю розпоряджаються своїми бюджетними доходами, відповідно вони не мають можливостей для максимально ефективного використання інтегрального потенціалу території. По-друге, у функціонуванні міст першим за значимістю виступає житловобудівельний сектор. Будівництво здійснюється за рахунок авансових платежів жителів, а забудовник займає зручні для нього площі на окраїнах міст під майбутні інфраструктурні зобов'язання або порушує історичні центри, коли нові багатоповерхові будинки вбудовуються в тканину історичних архітектурних ансамблів. Надмірне збільшення забудованих площ призводить до розтягування комунікацій, витрат на будівництво інфраструктури, ускладнення логістики для жителів, надмірних часових і фінансових витрат домогосподарств, погіршення екологічної ситуації, прогресуючих «міських» хвороб.

Це дає підстави для висновку про те, що на сучасному етапі управління міським розвитком фактично відсутнє. Замість нього застосовується ряд розрізнених і не пов'язаних між собою практик освоєння коштів і простору. Відсутність ефективних стратегій розвитку міст $є$ третьою i головною перешкодою на шляху поліпшення якості життя населення як міст, так i, значною мірою, сільських територій.

\section{Висновки}

Незважаючи на відсутність однозначного трактування поняття «урбанізація» і наявність неоднакових проблем міського розвитку в різних країнах, спільним для більшості урбанізованих країн став дисбаланс у вирішенні проблем розвитку міст різними відомствами і деградація міського середовища. 3 1980-тих років постає питання пошуку шляхів подолання проблем і узгодження цих шляхів 3 ціннісними орієнтирами сталого розвитку 3 метою поліпшення якості життя населення. Теоретичне обгрунтування концепцій міського розвитку з того часу значно змінилося: якщо в 1980-тих роках акцент робився на подолання негативних наслідків урбанізації, то у XXI столітті він зміщується на підтримку позитивних iii рис і модернізацію життя загалом, пізнання причин, за якими людина обирає те чи інше місто для проживання чи праці.

Згідно з суспільно-географічною концептуалізацією якості життя населення [9], ця категорія не підпадає під стандартизацію ISO. Кожна територіальна спільнота, виходячи зі своїх передумов, формує свої «ідеали» якості, індикативно позначає свій напрям руху до соціальної та екологічної безпеки, політичних та економічних свобод. Так i урбанізація: на різних історичних етапах вона має визначатися по-різному. В Україні у ХХ ст. урбанізація супроводжувалась зростанням міського населення, а також економічним піднесенням більшості іiі регіонів, у XXI ст. є потреба у переосмисленні соціальних, соціокультурних, екологічних, політичних наслідків цього процесу, який триває, але вже зовсім в інших формах, ніж раніше і ніж це відбувається у багатьох розвинених країнах нині. Людина, ii потреби у певному віці, умови для реалізації цих потреб все це має бути в центрі уваги в управлінні урбаністичним розвитком, і згадані у цій статті концепції розвитку міст це тільки підтверджують.

Процес децентралізації, який триває в Україні, має сприяти тому, щоб міська спільнота стала самостійнішою у власних управлінських рішеннях, у можливості розроблення й підтримки «своїх» індикаторів якості життя населення. Вважаємо, що зарубіжна практика інтегрованого підходу до розвитку міст стане в нагоді при імплементації цілей сталого розвитку в Україні та сприятиме покращенню якості життя і комфорту як містян, так і селян.

Питання щодо механізмів упровадження конкретних проектних підходів у стратегічні плани розвитку міст і регіонів потребують подальших досліджень.

\section{References [Лimepamypa]}

1. Ageing in Cities: Policy Highlights (2015). OECD. Paris. URL: http://www.oecd.org/cfe/regional-policy/Policy-BriefAgeing-in-Cities.pdf

2. Aldous T. (1992). Urban Villages: A Concept for Creating Mixed-use Urban Developments on a Sustainable Scale. 2 ed. London. 
3. Averkina M.F. (2012). Influence of the theory of sustainable urban development on the theory of urbanism. Scientific Notes of Ostroh Academy National University, Series: Economics. Iss. 19, 262-266. [In Ukrainian].

[Аверкина М.Ф. Вплив теорії стійкого розвитку міст на теорії урбаністики // Наукові записки Національного університету «Острозька академія». Сер.: Економіка. 2012. Вип. 19. С. 262-266.]

4. Downton P. (2009). Ecopolis. Architecture and Cities for a Changing Climate. Dordrecht.

5. Dronova O.L., Lys Ya.S. (2016). Management of Urban Agglomerations: European Experience for Reforms in Ukraine. Ukrainian geographical journal, 1, 47-52. [In Ukrainian].

[Дронова О.Л., Лис Я.С. Управління міськими агломераціями: європейський досвід для реформ в Україні // Укр. геогр. журн., 2016. №1. С. 47-52.]

6. $\quad$ Functions of cities and their influence on the space / ed. L.H. Rudenko (2015). Kiev. [In Russian]. [Функции городов и их влияние на пространство / под ред. Л.Г. Руденко. Киев, 2015. 292 с.]

7. Glaeser E. (2010). Triumph of the City: How Our Greatest Invention Makes Us Richer, Smarter, Greener, Healthier, and Happier. London.

8. Gornova G.V. (2010). Urban discourse of Western philosophy of the twentieth century. Bulletin of the Chelyabinsk State University, 16, 180-187. [In Russian].

[Горнова Г.В. Урбанистический дискурс западной философии ХХ века // Вестник ЧелГУ, 2010. № 16. С. 180-187.]

9. Gukalova I.V.(2009). Quality of life of the population of Ukraine: human-geographical conceptualization: monograph, Kyiv. [In Ukrainian].

[Гукалова I. В. Якість життя населення України: суспільно-географічна концептуалізація: монографія. Київ, 2009. 347 c.]

10. Gukalova I.V., Omelchenko N.V. (2015). Category «urbanization» in the conceptual field of social geography and other sciences. Odessa National University Herald, Series: Geography and Geology. Vol. 20. Iss. 2 (24), 96-109. [In Ukrainian].

[Гукалова І.В., Омельченко Н.В. Категорія «урбанізація» у понятійній площині соціальної географії та інших наук // Вісник Одеського нац. ун-ту. Серія «Географічні та геологічні науки». 2015. Т. 20. Вип. 2(24). С. 96-109.]

11. Integrated development of Ukrainian cities. URL: https:/www.giz.de/en/worldwide/40007.html [In Ukrainian].

[Інтегрований розвиток міст України. URL: https://www.giz.de/en/worldwide/40007.html]

12. Jacobs D. (2011). Death and life of large American cities. Moscow. [In Russian]. [Джекобс Д. Смерть и жизнь больших американских городов. Москва, 2011. 460 с.]

13. Lomonosov D.A. (2014). Quality of the urban environment and quality of life as the main criteria of the city development. Problems and prospects of cooperation between South-Eastern Europe countries within the Black Sea Economic Cooperation and GUAM, Vinnitsa, 166-169. [In Ukrainian].

[Ломоносов Д.А. Якість міського середовища та якість життя - головні критерії розвитку міста // Проблемы и перспективы развития сотрудничества между странами Юго-Восточной Европы в рамках Черноморского экономического сотрудничества и ГУАМ: сб. науч. тр. - Винница, 2014. С. 166-169.]

14. Mozhovyi A.A. (2016). Conflicts of Urban Development in Ukraine. Ukrainian geographical journal, 3, 39-43. [In Ukrainian].

[Мозговий А.А. Конфлікти міського розвитку в України // Укр. геогр. журн., 2016. №3. С.39-43.]

15. OECD Green Cities Programme. URL: http://www.oecd.org/regional/greening-cities-regions/46811501.pdf

16. Official site of The Congress for the New Urbanism. URL: https://www.cnu.org/resources/what-new-urbanism

17. Poklyatskyi S.A. (2016). Living conditions of the population of large cities of Ukraine: human-geographical research. Kyiv. [In Ukrainian].

[Покляцький С.А. Умови життя населення великих міст України: суспільно-географічне дослідження. Київ. 2016. 184 c.]

18. Register R. (1987). Ecocity Berkeley: Building Cities for the Healthy Future. Berkeley.

19. Sklyaruk N.I. (2003) Formation of a strategy for the development of small cities economy in the context of market reforms: author's abstract for obtaining Candidate of Economical Sciences Degree, Kharkiv. [In Ukrainian].

[Склярук Н. I. Формування стратегії розвитку економіки малих міст в контексті ринкових реформ: автореф. ... канд. екон. наук, Харків, 2003. 24 с.]

20. Urban Ukraine: in the epicenter of spatial changes: monograph / ed. K. Mezentsev, Ya.Oliynyk, N.Mezentseva (2017). Kyiv. [In Ukrainian].

[Урбаністична Україна: в епіцентрі просторових змін: монографія /за ред. К. Мезенцева, Я. Олійника, Н. Мезенцевої. Київ, 2017. 438 с.]

21. Voloshinskaya A.A. (2017). Evolution of foreign concepts of urban development: analysis of main trends. Public administration. Electronic bulletin, 63, 99-115. URL: http://e-journal.spa.msu.ru/uploads/vestnik/2017/vipusk_63. avgust_2017_g./63_2017.pdf [In Russian].

[Волошинская А.А. Эволюция зарубежных концепций городского развития: анализ основных тенденций / Государственное управление. Электронный вестник, 2017. Вып. 63. C. 99-115. URL: http://e-journal.spa.msu.ru/ uploads/vestnik/2017/vipusk_63._avgust_2017_g./63_2017.pdf].

22. Vuchic V.R. (1999). Transportation for Livable Cities. New Brunswick.

Стаття надійшла до редакції 04.02.2018 